\title{
Welcome to Country
}

\section{Acknowledgement, Belonging and White Anti-racism}

\section{EMMA KOWAL}

DEAKIN UNIVERSITY

I wish to acknowledge the traditional custodians of the land we are meeting on, the Ngunnawal people. I wish to acknowledge and respect their continuing culture and the contribution they make to the life of this city and this region. I would also like to acknowledge and welcome other Aboriginal and Torres Strait Islander people who may be attending today's event. ${ }^{1}$

I would like to also acknowledge my own and your own ancestors and all the diverse places they were born in and journeyed to. I would like to acknowledge the injustices committed by many of our ancestors who journeyed to new lands, as well as the injustices that caused many to journey from their homes. I honour the courage it takes to make a new life in a new place, and to welcome newcomers. I also acknowledge the ancestors that we share with others in this room, whether those shared 
ancestors are hundreds, thousands, or tens of thousands of years in our

past. 2

Can I particularly acknowledge all of those, past and present, including our indigenous communities, whose love of this land has made this a place we treasure and a state we all seek to nurture. ${ }^{3}$

\section{-INTRODUCTION}

On 12 February 2008 in the Australian Parliament, incoming Prime Minister Kevin Rudd delivered a historic apology to thousands of Aboriginal children removed from their families through much of the twentieth century-collectively known as the Stolen Generations. Many media reports of this high point of reconciliation also mentioned an innovation Rudd introduced that day, one that has been repeated annually at the first sitting of Parliament-a 'Welcome to Country' (WTC) a ritual performed by a Traditional Owner of Canberra, the nation's capital. ${ }^{4}$ Over the past few decades, in many sectors of Australian life the practice of inviting a representative of a local Indigenous group to 'welcome' the audience onto Aboriginal country has become commonplace. A WTC is conducted by a person recognised as an 'elder' and is most often a short speech, incorporating words or phrases of Aboriginal language. Larger events can involve dance, music or a smoking ceremony (a ceremony involving culturally significant smoking bushes).

The twin ritual of a WTC is an Acknowledgement. This is where a nonindigenous person (or an Indigenous person who is not a Traditional Owner) acknowledges that the site where the audience is meeting is regarded as ancestral country for a particular Aboriginal or Torres Strait Islander nation and acknowledges the elders of those Traditional Owners. ${ }^{5}$ An Acknowledgement may be performed in response to a Welcome, or in place of a Welcome when the event is too small for a WTC or when a planned WTC does not occur.

The first WTC ceremony was performed in Perth in 1976 by members of the Middar Aboriginal Theatre at the request of visiting Maori and Cook Island dancers. ${ }^{6}$ Such ceremonies were promoted by the Council for Aboriginal Reconciliation in the 1990 s and soon became widespread. ${ }^{7}$ An indication of their reach is reflected by an 
internet search for 'Welcome to Country protocols', conducted by the author in July 2015, that found 6.7 million hits. Scanning the first ten pages of results indicated that many government departments and bodies (at local, state, territory and federal levels), most universities, large corporations (for example, Australia's major banks, the Australian Football League), Aboriginal organisations (for example, land councils, health services), professional organisations (such as law societies, the Planning Institute) and non-government organisations with a social justice focus (such as Reconciliation Australia and the Diversity Council of Australia) have formal protocols that typically outline the circumstances in which a WTC or Acknowledgement should be held (essentially any public or semi-public event, such as conferences, meetings or the openings of new facilities), how it should be organised, levels of remuneration and suggested wording.

Welcome to Country protocols are often produced as part of or alongside a Reconciliation Action Plan (RAP). Launched in 2006 by Reconciliation Australia (the organisation formed to carry on the work of the Council for Aboriginal Reconciliation when it ended in 2000), a RAP describes a process where 'organisations develop business plans that document what they will do within their sphere of influence to contribute to reconciliation in Australia'.8 Reconciliation Australia recommends that RAPs include protocols for WTCs and Acknowledgements. Depending on the nature of the organisation developing the RAP, they may also include recruitment targets for Indigenous employment, programs for building partnerships with local Indigenous communities and a mechanism for measuring progress against targets that are reported to Reconciliation Australia. Although there is no way of quantifying WTCs and Acknowledgements, which probably occur by the hundreds every day, an indirect measurement can be found in the number of organisations that have adopted RAPs. The latest data available on the Reconciliation Australian website from 2012 tells us that 358 organisations had a RAP, and 1.7 million Australians worked or studied at these organisations. ${ }^{9}$ Another important indication of the spread of WTCs and Acknowledgements is their widespread use in Australian parliaments. In addition to the federal Parliament, all state parliaments except Victoria (of which more later) and Western Australia include a formal Welcome to Country ceremony at some point during each calendar year. ${ }^{10}$ 
It is fair to say that the rituals are now firmly ingrained within certain segments of Australian society, particularly government, university and non-government sectors. To many Australians who speak in public or organise events they have become routine. This essay will explore the varying and diverging meanings of the rituals, but focus on their function as White anti-racist 'speech acts'11 that perform 'identity work' for White Australians who wish to address and overcome the legacy of colonialism. ${ }^{12}$ At the most basic level, a non-indigenous audience appreciatively watching a WTC ceremony or non-indigenous speaker acknowledge Traditional Owners, positions themselves as 'anti-racist'. Alternatively, rejecting or mocking a WTC or Acknowledgement can establish the viewer as a 'conservative', or, from the point of view of progressives, a 'racist'.

While this is a useful starting point for understanding the identity work of these rituals, this essay argues that the meaning of WTCs and Acknowledgements extends far beyond a political insignia. In fact, the reason they are so effective at parsing out political positions is because they are potent commentaries on belonging. ${ }^{13}$ The three Acknowledgements that serve as epigraphs to this article illustrate conflicting approaches to belonging. The first, the University of Canberra's suggested script attributed to the United Ngunnawal Elders Council, is a conventional Acknowledgement replicated with minor variations across the country. The second is an addendum that extends Acknowledgement of Traditional Owners to encompass non-indigenous origins and ancestors. The third was suggested by former Victorian conservative premier, Ted Baillieu, as an alternative to a conventional Acknowledgement. Soon after taking over office from Labor Party premier Steve Bracks in 2010, he controversially removed his predecessor's policy that required government ministers to acknowledge Traditional Owners when making public speeches. Baillieu's Welcome emphasises affect and nurture, not traditional ownership, as a basis for belonging, and positions Indigenous people as one group among many. Later we will get to a Welcome penned by high-profile conservative commentator Andrew Bolt which does not mention Indigenous people at all.

The second and third Acknowledgements share a concern to include nonindigenous people within their ambit. However, I will argue for a crucial distinction between a defensive Acknowledgement that excludes Indigenous ownership, such 
as Baillieu's, and an inclusive Acknowledgement of multiple origins and precursors alongside a conventional Acknowledgement of traditional ownership, such as mine.14 An inclusive Acknowledgement can make explicit the unease that Acknowledgements express and generate about sovereignty, belonging and the provisional unity that is the Australian nation. It can encourage constructive social commentary on the contradictions stitched into the fabric of post-settler Australian society: issues of origins and ownership, inhabiting and belonging, love and labour, a distinctive Indigeneity and a common humanity.

Let me make it clear at this point that for some people, including some scholars affiliated with Whiteness studies I discuss below, the possibility of an inclusive Acknowledgement' may be beyond the pale. A WTC/Acknowledgement is a political act of defiance in the face of originary and ongoing dispossession, marginalisation, racism and genocide. It is a small sign of solidarity with Indigenous people and recognition of the theft and violence that founded and fuels the Australian national project. As an anthropologist of Indigenous-state relations and White anti-racism, the political importance of these rituals, along with their bureaucratisation and extent, make them attractive as objects of analysis. But for some, examining WTCs and Acknowledgements as expressions of belonging is incompatible with their political functions. Any exploration of non-indigenous belonging in the Australian nation-state is considered by definition to be at the expense of Indigenous belonging. From this point of view, Indigenous claims are automatically diluted, dissolved or negated when mentioned alongside other kinds of belonging. An Acknowledgement that includes non-indigenous people in its scope is therefore oxymoronic.

The assumption of my approach is that belonging is not a zero sum game. ${ }^{15}$ Non-indigenous belonging and Indigenous belonging, while often in conflict, can coexist in theory, and recognition of one does not necessarily negate the other. ${ }^{16}$ Opening up conversations about reciprocal recognition is a risky prospect in a cunning post-settler state, but in my view this is a risk worth taking. ${ }^{17}$ More, it is a risk we have to take. It is imperative that we find ways to recognise all kinds of belonging in a manner that promotes mutual flourishing-or at least that we retain hope that such modes of recognition are possible.18 Some will disagree, including those conservatives who cannot tolerate any form of Indigenous recognition, and 
those progressives who cannot abide any discussion of non-indigenous belonging. ${ }^{19}$ I suggest such readers read no further. For those who remain, what follows is an attempt to analyse the debate about WTC and Acknowledgement rituals for what it tells us about belonging in contemporary Australia.

When I sent out an enquiry to the Australian Anthropological Society listserv in 2009 on this topic, very little research on the topic had been published. ${ }^{20}$ However, some members shared their personal views about WTC and acknowledgement rituals. In the time since then, controversies about these rituals have periodically surfaced in the Australian media. My analysis draws on these controversies, the scant academic work on this issue, the email responses to my query and my ethnographic study of non-indigenous people who work in Indigenous health.

The latter study comprised fieldwork at the pseudonymous Darwin Institute of Indigenous Health, a research institute in Darwin, the capital of Australia's Northern Territory, in 2004-05. My informants were largely White, middle-class, progressive, educated professionals who had moved to Darwin from metropolitan centres to apply their expertise to the problem of Indigenous disadvantage. I refer to this group, of which I was a member, as 'White anti-racists'. Elsewhere, I have written about the work that White anti-racists do to create and maintain their identities and remain intelligibly 'anti-racist' to Indigenous and non-indigenous observers. ${ }^{21}$

In my terms, 'anti-racist' is not an evaluative label that seeks to judge whether a person is effectively reducing the sum of racism in the world (apart from anything else this would be a serious methodological challenge). Rather, I am using 'antiracist' in an anthropological sense to denote those associated with a common identity and culture of 'people who oppose racism'. 'Anti-racists' are not a collective in any formal sense, but congregate around certain organisations (for example, Reconciliation Australia, refugee advocacy groups), news outlets (like New Matilda or Green Left Weekly), and are often found in educational, bureaucratic and NGO settings. Those who comfortably identify or are identified by others as 'anti-racist' are highly diverse, but tend to exhibit a common array of behaviours that makes them recognisable as anti-racist, behaviours that include organising or enjoying WTCs and performing Acknowledgements.

The job of remaining visibly anti-racist is a difficult one because Whiteness itself is a 'stigma' within the spaces of Indigenous affairs, spaces where there is a 
deliberate attempt to invert colonial power relations. ${ }^{22}$ It must be stressed here that to align the terms 'Whiteness' and 'stigma' could seem extremely odd from the point of view of Whiteness studies, a field that has spent two decades exploring how White privilege shapes diverse societies. ${ }^{23}$ Indigenous Australian scholars have made critical contributions to this literature, exploring how Whiteness is expressed in settler colonies like Australia through an investment in white possession of territory, explored by Aileen Moreton-Robinson as the 'possessive logic of patriarchal white sovereignty' that erases Indigenous sovereignty, perpetually enacting and re-enacting Indigenous dispossession. ${ }^{24}$

White anti-racists benefit from White privilege as they go about their everyday lives, willingly or unwillingly. However, in particular spaces like the Darwin Institute, efforts to counter White privilege mean that White privilege itself is paradoxically stigmatised. The result of anti-racist measures like all-Indigenous ethics committees with veto rights over research projects and affirmative action mean that White privilege and its effects are far more explicitly acknowledged and problematised than they are in other spaces. At the Darwin Institute, most white anti-racists are keenly aware of the links between their Whiteness and privilege and the colonisation and ongoing oppression of Indigenous people. ${ }^{25}$ As a result, they experience their Whiteness as a stigma-a mark of shame. Elsewhere, I have argued that certain behaviours observed among White anti-racists are best understood as attempts to manage this stigma. White anti-racists fear that any action they will take will harm Indigenous people, just like their colonising and assimilationist predecessors. To manage this, White anti-racists may diminish or deny their own agency in projects, for example by attributing positive outcomes solely to the actions of Indigenous people, or avoiding appearing in or literally erasing their own presence from project photos or videos. ${ }^{26}$

Sara Ahmed's foundational 2004 essay on the 'non-performativity' of Whiteness would frame these White anti-racists differently. ${ }^{27}$ She argues that a range of speech acts that position White anti-racists as 'not racist' in fact reinforce White privilege and recentre Whiteness by allowing the White anti-racist to locate racism somewhere else and claim to transcend it, in effect taking the high moral ground over conservatives. In saying they are concerned with and knowledgeable about White racism and Indigenous dispossession, Ahmed would argue, they fail to 
take responsibility for their ongoing role in perpetrating, maintaining and benefiting from Indigenous dispossession and racism. I suspect Ahmed would consider statements acknowledging the Traditional Owners, the work of organising WTC ceremonies and the other acts of White anti-racism I discuss in this article as examples of non-performative anti-racism.

My concept of 'White stigma' broadly correlates with Ahmed's analysis (although she may not like my terminology). The stigma of privilege is that which White anti-racists try to 'transcend' (I would say 'manage') through speech acts (drawing on my ethnographic research, I can analyse behaviours alongside speech acts). Where we part company is our approach towards those White anti-racists who are troubled by racism and disadvantage and seek to do something about it. In my reading of Whiteness studies, there is no way for anti-racists to act without reinforcing their privilege. ${ }^{28}$ The acceptable modes of action for White anti-racist subjectivities are silence (for example, Dreher's 'eavesdropping with permission') and experiencing the discomfort and self-loathing of being the source of pain for others without seeking relief or resolution. ${ }^{29}$ In the context of this article, a third aspect to note is non-belonging. As Riggs sees it, the aim of 'Critical Whiteness Studies' 'should not be about making non-indigenous people "comfortable", but should instead continue to destabilise the assumptions of privilege that inform nonindigenous belonging. ${ }^{30}$

I have explored the first two aspects in other work through the terms 'disappearance' and 'suffering'. ${ }^{31}$ My view, expressed in that research, is that silent and suffering anti-racist subjectivities may be appropriate and useful for academics, but they are incompatible with effective work in Indigenous affairs. The even larger wager of this article is that silent, suffering anti-racist subjectivities that don't belong are not up to the prodigious task of charting paths to coexistence in this settler society.

But I am getting ahead of myself. This article first explains how I approach WTC and Acknowledgement ceremonies as anti-racist speech acts that maintain White identities and manage White stigma by questioning White belonging. I weave discussion of the multiple and contradictory meanings of the rituals into a broader argument about White anti-racist 'performances' and political contestations between conservative and progressive commentators. I argue that widespread 
enjoyment of these rituals among White anti-racists is explained because they paradoxically experience belonging through a sense of not belonging. ${ }^{32}$ More broadly, WTC and Acknowledgement rituals can most usefully be thought of as a device to encourage reflection on belonging. Such an approach acknowledges the challenge to White belonging posed by WTC rituals and keenly felt by conservative Australians. I conclude that although an inclusive acknowledgement of diverse origins and journeys alongside traditional ownership is a risky prospect, it can usefully encourage reflection on belonging, challenging both conservative desires to ignore traditional ownership and progressive desires to delegitimise nonindigenous forms of belonging. ${ }^{33}$

-PERFORMING ANTI-RACISM

Reading Acknowledgements as White anti-racist speech acts draws on an understanding of identity as performed through linguistic and non-linguistic means, following sociologist Erving Goffman. Individually and in groups, we present ourselves through a combination of conscious and unconscious gestures and words, with intentional and accidental mistakes. In the backstage, where audience members are forbidden, group members can refine the performance without the pressure of staying in character. ${ }^{34}$ As a 'native ethnographer' of White anti-racist people, my observations concern both the front of stage and backstage. 35 Physically, the backstage consisted of the corridors of the institute, the tearoom, closed meetings of researchers or social gatherings on back verandas. In the front of stage, White antiracist subjectivities are cultivated and preserved.

Considerable effort is devoted to making sure the front of stage looks and sounds consistent with anti-racist subjectivities, whether it is a seminar, conference or academic publication. ${ }^{36} \mathrm{~A}$ WTC is but one example of the many factors an antiracist must keep in mind. For instance, the number of Indigenous presenters at an event should be at least equal to the number of non-indigenous presenters-a stage full of White people discussing Indigenous issues is a bad look. Though, if some of the people on stage that appear White are in fact Indigenous, any overt, whispered or unspoken criticism from the audience is not a concern, as any such criticism simply portrays the critic as ignorant at best, and racist at worst, for assuming that a pale-skinned person is not Indigenous. Non-indigenous dark-skinned people are 
intermediate in their visual impact-better than a White person, but not as good as an Indigenous person. Gender balance is important too-ideally, Indigenous men and Indigenous women should be equally represented. The appearance of White women on stage is generally slightly better than White men. If there are questions taken from the audience, the facilitator will be keen to call on any Indigenous people that raise their hand to speak, to show they are creating a space where Indigenous voices are heard.

Listing these concerns as I have just done may create the impression that I am trivialising or mocking these efforts, particularly as trivialising and mocking are major pastimes of the conservative press (of which more later). I respect the intentions of those who make these efforts, and recognise the outcomes of those efforts, for example greater Indigenous participation, are both tangible and important. Further, White anti-racists are not constructing these complex algorithms of representation in a vacuum, but responding to the concerns expressed by Indigenous people. ${ }^{37}$ Making explicit this knowledge of 'how to be an anti-racist' seems distasteful in print, although it is acceptable to talk of these things, if somewhat obliquely, in conference planning meetings. The techniques required to privilege Indigenous voices are employed tacitly on the backstage and are not for consumption by a public audience.

There are a limited number of people who feel comfortable speaking from a stage to a large audience, and many of those people who are Indigenous are inundated with requests to speak or serve on committees or contribute to publications. Consequently, they are liable to refuse requests to speak publicly if it comes from someone they don't know well (particularly as most requests to speak at events, aside from WTCs, are unpaid). If event organisers succeed in producing an appropriate list of presenters on the program, a Traditional Owner to perform the Welcome to Country, the right balance of indigeneity, gender, professional background or whatever else is relevant to the event, this is itself an indication of the merits of the organisers. It demonstrates their ability to recognise what was required, and shows their personal ties to the Indigenous speakers are sufficient for these busy people to agree to participate. This is, however, far from the end of the story. 
In my experience it is not uncommon for speakers to fail to turn up, or to leave unexpectedly. When these speakers are Indigenous these absences are most often explained to the audience as 'family issues', or sometimes 'cultural issues'. With the high rates of illness, death, incarceration, violence and other stressful life events suffered by Indigenous families, this is not surprising. However, I'm interested here in how the failure of an invited Indigenous presenter to turn up is an opportunity for White people to further display their anti-racism. The example below is from a workshop on Indigenous health research I attended. The main facilitator was an older White man who had a senior position; Kylie, who held a mid-level role, was scheduled to present a session:

He introduces the other facilitators, noting that Kylie had to leave soon after arriving this morning: 'she's had some urgent family matters she needs to attend to, they were unexpected. She will hopefully join us later in the day and we wish her well with her family.'38

Through Kylie's absence, the facilitator was able to demonstrate his ability to be culturally sensitive and to be flexible enough to accommodate Indigenous cultural needs whenever they arose. He was also able to counter racist generalisations about the unreliability of Indigenous people with his unselfconscious gesture of sympathy, wishing her well on behalf of all of us. The mainly White audience had an opportunity to not react, to not blame or judge, exhibiting their anti-racism. His explicit comments acted to silence (but also, paradoxically, highlight through demonstrating the need to silence) the ideas that are certainly not voiced, and perhaps barely thought: musings about whether Kylie really had a family emergency, or perhaps was disorganised enough to be double-booked, or behind in her paid work, or offended at being asked to be a 'token black' by the organisers, or maybe she had a gambling habit and went off to the casino. Some of these imaginings would have raised the possibility that her absence was a snub to the organisers, undermining their implicit claims to have meaningful relationships with Indigenous people. Because if they did, Kylie would care enough to stick around. It was this smoulder of inchoate musings that necessitated the facilitator's careful words. A WTC ceremony that fails to eventuate may generate similar racialised imaginings. 
A similar set of performances was evident at another workshop where a scheduled Indigenous presenter was not able to attend. The main facilitator, again a White man, apologised to the audience as he began the section on Indigenous research methodologies:

Today I'm the default presenter, it was just not possible for it to be otherwise this morning. ${ }^{39}$

Effectively, he is apologising for being White. An Indigenous co-facilitator sits beside him as he clicks through the Power Point slides. I am sure he is aware of the negative visual impact of a White man speaking authoritatively about Indigenous knowledge systems while the Indigenous woman next to him remains silent. One can only imagine that he implored her, she whose identity was better suited to the task, to read out the notes accompanying the slides instead of him when the scheduled presenter failed to turn up. But for whatever reason (lack of confidence? lack of familiarity with the material? resentment she was being asked just because she was Indigenous?), she had declined.

The effort of organising, of trying, but of calmly accepting when it all goes wrong, is also the performance of anti-racism. Unsuccessful anti-racism is perhaps the most common form of anti-racism, perhaps its highest form. It is accepting responsibility and not getting angry, avoiding blame, submitting to White stigma, to the inevitability of one's oppressiveness. The White anti-racists in the audience may have interpreted the unspoken commentary of the facilitator's statement as follows: 'although I am a non-indigenous person presenting on Indigenous research methodologies it is not as it seems. I have not sought this role, I know I shouldn't be here, I'm only here because the Aboriginal people that could present, that in fact coauthored the document I am reading, are not here, for reasons it is not my business to question.' In spaces like the Darwin Institute, where contact between Indigenous people and anti-racists means that identity-maintenance is a perennial occupation, even the smallest event is imbued with a range of racialised meanings.

Monitoring one's language is crucial in such spaces. One example comes from a seminar where a non-indigenous speaker was explaining how Indigenous organisations developed a comprehensive critique of research practices from the 1980s onwards: 
Aboriginal organisations had grown up-that's a patronising thing to say-had emerged as organisations, were taking control of research. ${ }^{40}$

She recognised that she had slipped up in using the phrase 'grown up', a phrase that subtly suggests she was in a position of 'parent' to Aboriginal 'children'. Some may think she was being over-vigilant-that 'grown up' is a neutral phrase-but in the context of a White person talking about Indigenous people in public, she was right to expect that at least some of the audience might have taken offence, either Indigenous people, or non-indigenous people on their behalf.

In any case, whether or not some people in the audience would have been offended is beside the point. Through the opportunity to show her sensitivity to the possibility of offence, publicly admitting her tendency to oppression (in this case through being patronising) and substituting an unquestionably neutral term ('emerged'), she manages to exhibit her anti-racism. Her slip-up and consummate recovery demonstrate anti-racist attributes that might otherwise be difficult to exhibit.

These white anti-racist manoeuvres illustrate how WTC and Acknowledgement rituals can provide opportunities to demonstrate White anti-racist identities. An event organiser who chooses to schedule a WTC is displaying their symbolic recognition of Indigenous claims. Individual speakers who begin with an Acknowledgement make a personal statement of their anti-racist credentials. An Acknowledgement can act as a challenge or an accusation. For example, once the first speaker at a conference delivers an Acknowledgement, subsequent speakers must decide whether to follow suit. The absence of an Acknowledgement can imply a refusal to recognise Indigenous sovereignty or respect Indigenous culture.

I have described how identity maintenance drives White anti-racist speech acts, so that the failure of an Indigenous person to be present for a WTC is both a challenge to White anti-racist identities and an opportunity to bolster them by exhibiting cultural sensitivity. This applies at a collective level in the form of complex intra-community politics that White anti-racists must negotiate. As some who have organised WTC ceremonies will know, a WTC can transform from a hopeful political statement into a political nightmare. Competing claims of traditional ownership and group membership can mean arranging a WTC is a major exercise in diplomacy. 
The dispute between the 'one-n' Ngunawal and the 'two-n' Ngunnawal Traditional Owners of Canberra is perhaps the best-known example. One anthropologist told me how a Canberra Traditional Owner, to deflect accusations that she is not Ngunawal, has 'started using a new term the Ngunnawal-Ngambri tribe so non-Aboriginal people have to choose carefully which name they are using or be coopted into one side of the dispute'.41 Organisers of a WTC at Latrobe University in Wodonga in late 2009 were not careful enough to avoid a public community dispute. The WTC for a prominent annual oration erupted into anger when Indigenous members in the audience who believed the speaker was not a Traditional Owner loudly interrupted. The controversy concerned Aboriginal Elder and activist Gary Murray, who is described by the Border-Mail as a 'Dhudhuroa man' but who himself identifies as an Elder of the Dhudhuroa, Wamba Wamba and Dja Dja Wurrung nations. A university representative commented it was unfair on the university to be expected to make the right call when Aboriginal people were still divided'. ${ }^{42}$ This response is out of step with the individual white anti-racists I have described who would be unlikely to complain of unfairness. It seems that in this case, the public scale of the failure transcended the limits of anti-racist absorption and elicited a defensive response from a high-level university executive.

The material I have discussed above, while empirically sound, may be profoundly discomforting for White anti-racists. Revealing the 'backstage' manoeuvrings of White anti-racist performances can appear to belittle these efforts and provide fodder for conservative commentators. However, attempts to conceal these efforts, for example, by pretending that Indigenous communities do not have internal divisions and factions, creates its own problems.

The New South Wales Health Department guidelines on WTCs are illustrative here. The document suggests they have had some experience of community conflict and offers specific advice on the issue. In the event that there is a dispute over traditional ownership, they recommend 'acknowledge[ing] "all the traditional owners of this land" without naming those people'.43 This careful approach makes visible some of the contradictions of the practice. By covering over the contemporary disputes over traditional ownership, we present a more 'deserving' subject of acknowledgement (the anonymous Traditional Owner) at the expense of 
acknowledging the reality of contemporary Indigenous life, which includes contestations over identity, land affiliation and representation. ${ }^{44}$

While documents that obscure community politics may aim in part to protect WTC and Acknowledgement rituals from conservative critique, they may have the opposite effect, exposing the rituals to accusations of tokenism. ${ }^{45}$ Tokenism was a central platform of the public criticism of the rituals in the wake of Ted Baillieu's decision to make an Acknowledgement of Traditional Owners non-mandatory for Victorian government ministers. Tim Wilson, then policy director for right-wing think tank the Institute of Public Affairs, was reported as supporting Baillieu's new policy because 'obsessive acknowledgement can only belittle and undermine the intent of such statements'. ${ }^{46}$ Although Wilson's statement is couched as concern for the effectiveness of Acknowledgements in honouring Traditional Owners, many of the 299 comments on the online version of the article belie this. Many respondents react to the perceived affront of a WTC or Acknowledgement, claiming that Indigenous people are unduly privileged by the government and should be grateful for Western culture and that, as 'Australians', it is insulting to be welcomed to their own country. ${ }^{47}$

From a different perspective, anthropologist David Trigger has expressed similar concerns about tokenism. He notes that 'not repeating an acknowledgement (and sometimes not arranging a Welcome) is to try to avoid tokenism. My view is the repetitive acknowledgements from speakers at a conference, e.g., is embarrassingly tokenistic and trivialises the important issues at stake.' A refusal to participate in the Acknowledgement ritual can be a silent protest against the hypocrisy underlying an 'acknowledgement' that simply enables Whitefellas to publicly position themselves in relation to the 'idea' of recognising Aboriginal interests' 48

While the language of Trigger's concerns about tokenism is similar to that of Tim Wilson, the effects of the two statements diverge. A key difference is the site of their utterance and reproduction. Claims of tokenism in the national conservative newspaper the Herald Sun are a dog-whistle to those who object to WTC rituals and who feel disadvantaged by symbolic and material efforts to address Indigenous disadvantage. Similar claims uttered in the backstage of White anti-racist identity formation, such as a personal email or an academic journal, aim to analyse the 
Acknowledgement's function as a White anti-racist speech act and the discourses of belonging it expresses. As I have argued, such attempts to critically reflect on White anti-racist identity are always at risk of co-option by conservative critique. However, taking this risk is necessary if we are to elevate the national conversation on Indigenous recognition beyond knee-jerk reactions and elaborate performances.

\section{-Upsetting White IDENTITIES}

Constructive conversations about WTC and Acknowledgement rituals pose a challenge precisely because the rituals invoke strong emotions among supporters and critics alike. Take, for example, the former Victorian premier, Steve Bracks: 'The thousands and thousands of times I started my speech with an Aboriginal welcome, I always felt very strongly about it.' 49 An author of an online comment on a piece by Indigenous writer Luke Pearson (discussed below) argued that an Acknowledgement, like an apology, was the minimum owed to Indigenous people:

The Aboriginal people-undeservedly-endured the equivalent to apartheid. Outright genocide in places, stolen generation ... The list goes on. A symbolic 'Acknowledgement' just like the long awaited 'SORRY' is the least we could offer. It doesn't cost a penny and it shouldn't hurt. Anyone who lacks that basic degree of genuine goodwill doesn't deserve to live on this Land. 50

Other comments on Pearson's article discussed the importance of the ritual for reconciliation: 'I believe we can never have a better future for all Australians unless we acknowledge our past and at least show our indigenous fellow citizens some empathy, compassion and respect' (comments made by 'Sonny' and 'Confused2' at $\mathrm{ABC})$.

These themes point to the function of WTC and Acknowledgement rituals as an attempt at national healing in the same vein as former prime minister Kevin Rudd's apology to Australia's Indigenous peoples in relation to the Stolen Generations. 51 The acts of colonial dispossession and violence that founded the settler colony and the racist regimes that followed have created transgenerational psychic wounds among the Indigenous population..$^{52}$ These acts mean Australia suffers from a permanent need to transcend the role of perpetrator and smooth over unheeded calls for Indigenous sovereignty to create a cohesive, caring national narrative, a 
function served by the Reconciliation Movement of the 1990s.53 The WTC and Acknowledgement rituals, along with Kevin Rudd's apology to the Stolen Generations, may be the movement's greatest success story. ${ }^{54}$

Another aspect of the therapeutic effect of WTC rituals is enjoyment. Everett describes how '[s]pirited applause, much head nodding and warm smiles are common responses from White audiences to these speeches', particularly when they incorporate Indigenous languages. 55 This suggests that what is enjoyable about WTCs is not (just) the quality of the oration or dance, or the pure pleasure of proximity to the exotic. The nature of a WTC as a purely symbolic statement of Indigenous ownership means non-indigenous people can enjoy Indigenous culture and presence without feeling threatened by Indigenous sovereignty. ${ }^{56}$ This perhaps explains why WTCs are predominantly a feature of urban Australia, where native title claims are both most unsettling to non-indigenous Australians and most unlikely to succeed.57 The claims of Indigenous ownership made in a WTC are usually wholly symbolic, with little chance of achieving legal reality.

Nevertheless, from the point of view of Traditional Owners, a WTC can be a quasi land claim. In the case of the Darug people of Sydney, who have been unsuccessful in their native title claims, Everett argues that 'the making of symbolic land claims is an important way to publicly make their claims known and gain some recognition of the cultural foundation of those claims from Australian society'.58 In combination, these complementary roles of quasi land claim and symbolic statement of ownership create a paradox: 'The welcoming that occurs is done by those whose claims to prior ownership of that place have already been denied to those who already inhabit that place and do not recognise the claims of others [with nonindigenous Australians standing in for the Australian state]'.59

Indigenous scholar Victor Hart sees these contradictions as amounting to a form of 'epistemological violence': 'the violence comes from knowing that Welcome to Country is an iteration of terra nullius mythology where blackfellas can appear at the beginning of the event (i.e. the beginning of history) and then conveniently disappear whilst whitefellas do their serious "business"'.60 Kristina Everett documents one instance when Darug Traditional Owners refused to conveniently disappear at an event in Sydney. During a re-enactment of a frontier scene when settlers shot natives, Darug 'natives' remained on the stage long after their cue to 
leave: 'Voices speaking Darug language kept calling from the shrubbery, and a parade of dancers appeared moaning, groaning, clutching their stomachs, their heads, their hearts and then "dying" on the lawn of Old Government House', causing intense embarrassment to those present. ${ }^{61}$ By disrupting the narrative set by the WTC ritual-welcoming, then exiting-the Darug people, like the uncomfortably quarrelsome Wodonga Aboriginal community, exceeded and thus revealed the limits of anti-racist recognition. ${ }^{62}$

For those who hold conservative views, intense feelings of discomfort are not limited to when WTC ceremonies take unexpected turns. Any form of WTC or Acknowledgement is liable to make this group of Australians feel uneasy. Although some progressive commentators, like the one cited above, believe that an Acknowledgement 'shouldn't hurt', for many conservative Australians, they do.

The role of WTC and Acknowledgements as a tool of national healing is the most irksome for conservative Australians who find abhorrent the suggestion that there is anything to heal or apologise for. To people like Andrew Bolt, WTC ceremonies are an insult to the Australian state and people and a racist mechanism of division. As the headline to an article he wrote in the Herald Sun succinctly puts it: 'Welcome to Country ceremonies are racist and anything but welcoming to nonAborigines who were born right here.' He argues that WTC ceremonies and Acknowledgements should be replaced with a universal gesture that acknowledges all Australians and avoids mention of Indigenous claims, acknowledging 'that we meet on land that is yours, mine and every Australian's'.63 It is tempting to respond to Bolt's accusation of racism in kind. Indigenous writer Luke Pearson provides an example in his response to Ted Baillieu's decision to make an Acknowledgement non-compulsory for Victorian government ministers. His comments reiterate the function of a WTC as an anti-racist speech act, appropriating the accusation of tokenism as a positive attribute:

Any Minister who doesn't want to perform an Acknowledgement of Country is saying that they have such contempt for Aboriginal people, accurate Australian history and modern Australian values that they refuse to make even the smallest gesture of goodwill and respect ... These politicians do not respect Aboriginal people anywhere in Australia, or the millions of Australians who believe that this tiny gesture is not only 
essential, but nowhere near enough. It is a TOKEN gesture. It is meant to be a symbol of respect and understanding. ${ }^{64}$

By focusing on an Acknowledgement as a performance that positions the speaker as someone who cares about Indigenous people, Pearson accurately describes the ritual from an anti-racist perspective (similar to the analysis I offered above), but he fails to respond adequately to the source of conservative critiques. Pearson rallies those who are already anti-racist to the cause and invites them to share his view that those who don't wish to perform an Acknowledgement are essentially racist. Many supporters of Baillieu's WTC decision who commented on the article reporting his decision strongly objected to the claim that they are racist, with some echoing Bolt's counter claim that WTC ceremonies are racist because they divide Australians into 'Indigenous' and 'non-indigenous' categories. ${ }^{65}$ We have here two camps calling each other racist.

\section{—ACKNOWLEDGING DISCOMFORT}

I conclude this essay by sketching an alternative response to these critiques that moves beyond accusations and counter-accusations of racism. This response must begin with the acknowledgement that WTC rituals raise difficult questions about settler belonging and the unfinished business of Indigenous justice. Some contributors to the debate recognise discomfort as an important function. One comment on Luke Pearson's article argues that if 'Acknowledging the Traditional Owners ... makes Mr Ballieu uncomfortable it is probably doing its job ... those who do feel uncomfortable probably should. That's the beginning of understanding.'66 Stephanie Convery makes a similar point:

The truth is, there is a disconnect between political symbolism and action on Indigenous issues in Australia. The recognition of traditional owners, the welcome to country, is essential if only because it draws attention to this disconnect. It reminds the non-indigenous listener of the fact of their colonial heritage, of the continued existence of Indigenous people and culture, and their direct relationship to everyone who calls themselves Australian. Or at least, it should. 67

This reminder is precisely what Bolt wants to avoid, and precisely what White antiracist Australians including Whiteness Studies scholars want to embrace. For 
conservatives, belonging depends on denying any claims to Indigenous sovereignty (whether real or symbolic); for progressives, belonging depends on continually being reminded of such claims. These opposing responses to WTCs illustrate the properties of White stigma. ${ }^{68}$ The possibility of non-indigenous belonging is a source of stigma for anti-racists: their very presence on the Australian continent stands as a constant reminder of Indigenous dispossession. The unsettling effect of WTCs or Acknowledgement rituals is experienced as satisfying because it affirms existing discomfort. You do not belong here, you came here without our consent, the WTC tells us. You need to be welcomed because you have made yourself welcome. For conservatives, this subtext is offensive because it stigmatises White identity and negates their mode of belonging. For progressives, this speech act, whether received from an Indigenous speaker or self-spoken, acknowledges and thus lessens the White stigma already keenly felt. Through stigmatising Whiteness in a collective and public fashion, the White anti-racist paradoxically finds a more comfortable mode of belonging to the settler state.

White anti-racists can be dismissive of conservative anxieties about WTCs because they experience them as affirming their sense of belonging, and also because the act of dismissing them sets them apart from the 'racist' White people they seek to distinguish themselves from. But dismissing as racist those who feel uncomfortable with WTC ceremonies will do nothing to promote understanding of Indigenous issues among those who would agree with Ted Baillieu's decision, a group that includes very many Australians. Instead, we must be prepared to engage with those who recoil from the discomfort that WTC ceremonies can induce.

In other words, I concur with Ahmed that WTCs and Acknowledgements as White anti-racist speech acts are 'non-performative' in that they serve mainly to distinguish the speaker from 'those racists' over 'there'.69 But I do not endorse resolving this by White anti-racists resisting the relief of feeling 'good' and returning to a state of self-loathing, silence and non-belonging. Instead, they should reflect on their ambivalence about belonging in Australia, an ambivalence temporarily relieved in moments they can experience the discomfort of non-belonging. They should recognise that both their need to not belong and conservative needs to have their belonging unquestioned demand responses that do not involve convincing conservatives to become anti-racists. A better response is to develop deeper 
understandings of the complex and contradictory workings of belonging and nonbelonging on the continent. ${ }^{70}$

I return to the potential for an inclusive Acknowledgement that includes settlers and migrants in its ambit, deliberately shifting the ritual from an anti-racist speech act to a device for encouraging reflection on belonging. ${ }^{71}$ As I outlined in the introduction, inclusivity risks undermining Indigenous belonging. An inclusive addendum to a conventional Acknowledgement, like the one I proposed at the opening of this essay, could be taken as mimicking Ted Baillieu or as no better than Bolt's total exclusion of Indigenous people. At a minimum, such an Acknowledgement makes for an unconvincing anti-racist speech act and threatens the speaker's recognition as anti-racist. However, these risks are worth taking. The alternative is to supress, and thus intensify, the strong feelings of belonging and non-belonging that these rituals reflect and reproduce. Both anti-racists and conservatives would prefer to conceal challenges to their preferred modes of belonging: anti-racists by not mentioning settlers, and conservatives by not mentioning Traditional Owners or mentioning them only in passing. Acknowledging shared histories, journeys and ancestors, and laying bare the contradictory relations between settlers, migrants and Indigenous Australians are more productive ways to address anxieties about belonging that remain central to Australian identity.

Emma Kowal is Associate Professor of Anthropology in the School of Humanities and Social Sciences and Principal Research Fellow in the Alfred Deakin Institute for Citizenship and Globalisation at Deakin University.

\footnotetext{
-ACKNOWLEDGEMENTS

My research is supported by an Australian Research Council Discovery Early Career Research Award. Thanks to David Trigger, David Martin, Victor Hart, Peter Sutton, Grant McCall, Jeremy Beckett, Nicolas Peterson, David Nash, Francesca Merlan and two anonymous reviewers for useful comments and suggestions. Previously this essay was provisionally accepted and then rejected by Australian
} 
Humanities Review. I am grateful to Cultural Studies Review for having the editorial courage to engage with these questions.

\section{-NOTES}

1 ACT Government: Community Services, 'Welcome to Country', 2012,

<http://www.dhcs.act.gov.au/atsia/welcome_to_country>.

2 Acknowledgement addendum written by the author.

3 Ted Baillieu, cited in Andrew Bolt, 'Baillieu Made the Right Call on Welcome Ceremonies', Herald Sun, 6 December 2011, <http://www.heraldsun.com.au/opinion/baillieu-made-the-right-call-on-welcomeceremonies/story-e6frfifx-1226059908884>.

4 The term 'Traditional Owner' is widely used in Australia by Indigenous and non-indigenous people to refer to an Indigenous person who has customary obligations for a particular territory. The term is an intercultural product, and has been particularly shaped by the legislative framework of Native Title. For important critiques see E. Povinelli, The Cunning of Recognition: Indigenous Alterities and the Making of Australian Multiculturalism, Duke University Press, Durham and London, 2002; Simon Correy, 'The Reconstitution of Aboriginal Sociality Through the Identification of Traditional Owners in New South Wales', The Australian Journal of Anthropology, vol. 17, no. 3, 2006; and Barry Morris, 'Anthropology and the State: The Ties That Bind', Social Analysis: The International Journal of Social and Cultural Practice, vol. 47, no. 1, 2003. The term 'elder' is more widely and broadly used for an Indigenous person who is thought to hold knowledge and authority within their community. Both terms, and arguably any word in English, can be seen as a colonial imposition that distorts the precolonial social forms they attempt to approximate. 'Country' in the context of Indigenous Australian culture is a wider term than 'land' or 'area', describing a living, creative entity with a deep ongoing relationship with the humans responsible for it, rather than the passive piece of territory typically part of Western imaginations of land. Somebody's 'country' is that which they have traditional affiliations passed down from older relatives. An affiliation involves holding traditional knowledge of (for example) sites that are linked to creation stories, of plants and animals, of the language dialect associated with that country and of how to enter that country and welcome strangers to it.

5 The argument made in this article that WTC ceremonies challenge the sense of belonging for nonindigenous Australians may also apply to Indigenous Australians who are not Traditional Owners of a particular area. However, this possibility, and more broadly Indigenous interpretations of WTC ceremonies, are beyond the scope of this article. Also note that WTCs and Acknowledgements raise distinct issues-differences that warrant further research—but for the purposes of this article they are considered together.

${ }^{6}$ Amanda O’Brien and Lex Hall, 'Dingo Claims the First Welcome', Australian, 17 March 2010.

${ }^{7}$ K. Lambert-Pennington, 'What Remains? Reconciling Repatriation, Aboriginal Culture, Representation and the Past', Oceania, vol. 77, no. 3, 2007. 
${ }^{8}$ Reconciliation Australia, 'Reconciliation Australia: Reconciliation Action Plans', $<$ http://www.reconciliation.org.au/raphub/about/>.

${ }^{9}$ Ibid.

10 Mark McKenna, 'Tokenism or Belated Recognition? Welcome to Country and the Emergence of Indigenous Protocol in Australia, 1991-2014', Journal of Australian Studies, vol. 38, no. 4, 2014, pp. 477-8.

11 J.L. Austin, How to do Things with Words: The William James Lectures delivered at Harvard University in 1955, Oxford University Press, London, 1962.

12 My use of the term 'White' in this article is informed by Whiteness studies (see footnotes below for key references in the field). It refers to a social category of people who are interpellated as White in their everyday interactions and who identify with or are identified with the dominant social group in Australian and many other societies. This group includes people who have white skin, but also includes those who may not identify as White but who benefit from the racialised social structure of White privilege by virtue of other features (such as socioeconomic status, geographical location or education). 13 Some key works on belonging and Australian identity include G. Hage, Against Paranoid Nationalism: Searching for Hope in a Shrinking Society, Pluto Press, Annandale, 2003; G. Hage, White Nation: Fantasies of White Supremacy in a Multicultural Society, Pluto Press, Annandale, 1998; A. MoretonRobinson, 'I Still Call Australia Home: Indigenous Belonging and Place in a White Postcolonizing Society', in S. Ahmed, C. Castaneda, A. Fortier and M. Sheller (eds), Uprootings/Regroundings: Questions of Home and Migration, Berg, Oxford, 2003; Anthony Moran, Australia: Nation, Belonging and Globalization, Routledge, New York, 2005; Anthony Moran, 'Trust and Uncertainty in a Settler Society: Relations between Settlers and Aborigines in Australia', in Sean Watson and Anthony Moran (eds), Trust, Risk and Uncertainty, Palgrave Macmillan, New York, 2005; Catriona Elder, Being Australian: Narratives of National Identity, Allen \& Unwin, Sydney, 2007; and K. Gelder and J. Jacobs, Uncanny Australia: Sacredness and Identity in a Postcolonial Nation, Melbourne University Press, Melbourne, 1998.

${ }^{14}$ As I hope will become clear, I offered my addendum above not as a prescription for how best to Acknowledge, but as a heuristic tool, and to signal that I am not a disinterested observer but am among the fray of Acknowledgement-givers and Welcome-receivers.

15 In focusing on belonging I am aware that I am eliding the concept of ownership, a move some will see as suspiciously convenient for my argument that belonging is not a zero-sum game, as prior ownership 'cannot be shared' (F. Probyn, 'An Ethics of Following and the No Road Film: Trackers, Followers and Fanatics', Australian Humanities Review, vol. 37, 2005.). Suffice to say here that the relationship between belonging and ownership deserves further attention but is outside the scope of this article. ${ }^{16} \mathrm{An}$ important point here (but one I do not have the space to explore) is that increasing numbers of Indigenous Australians who recognise both Indigenous and non-indigenous ancestry write and talk about the experience of multiple and coexisting forms of belonging; see Y. Paradies, 'Beyond Black and 
White: Essentialism, Hybridity and Indigeneity', Journal of Sociology, vol. 42, no. 4, 2006; Lynette Russell, “"Either, or, Neither Nor”: Resisting the Production of Gender, Race and Class Dichotomies in the Pre-Colonial Period', in Eleanor Conlin Casella and Chris Fowler (eds), The Archaeology of Plural and Changing Identities, Springer, US, 2005; Marianne Riphagen, 'Black on White: or Varying Shades of Grey? Indigenous Australian Photo-media Artists and the 'Making of' Aboriginality', Australian Aboriginal Studies, no. 1, 2008; and L. Fitznor, 'Indigenous Scholars and Writing through Narratives and Storying for Healing and Bridging', in Laara Fitznor and Joy Hendry (eds), Anthropologists, Indigenous Scholars and the Research Endeavour: Seeking Bridges towards Mutual Respect, Vol. 5, Routledge, New York, 2012.

17 Povinelli. See F. Merlan, 'Recent Rituals of Indigenous Recognition in Australia: Welcome to Country', American Anthropologist, vol. 116, no. 2, 2014 for a recent reading of Welcome to Country ceremonies as a troubled site of recognition.

18 I. M. Young, Justice and the Politics of Difference, Princeton University Press, Princeton, 1990 and E. Povinelli, Economies of Abandonment: Social Belonging and Endurance in Late Liberalism, Duke University Press, Durham, 2011.

19 My use of 'conservatives' and 'progressives' is explained further in footnote 33, but for now, conservatives are encapsulated by media commentators Andrew Bolt and Alan Jones, and conservative academics such as Keith Windschuttle (K. Windschuttle, The Fabrication of Aboriginal History, Macleay Press, Sydney, 2002.); 'progressives' are encapsulated by academics affiliated with Whiteness studies such as Suvendrini Perera (S. Perera, 'Who Will I Become? The Multiple Formations of Australian Whiteness', Australian Critical Race and Whiteness Studies Association Journal, vol. 1, 2005), Fiona Probyn (Fiona Probyn, 'Playing Chicken at the Intersection: The White Critic of Whiteness', Borderlands, vol. 3, no. 2, pp. 14-29), Fiona Nicoll (Fiona Nicoll, “'Are you calling me a racist?": Teaching Critical Whiteness Theory in Indigenous Sovereignty', Borderlands, vol. 3, no. 2, 2004), Jane Haggis (J. Haggis, 'Beyond Race and Whiteness? Reflections on the New Abolitionists and an Australian Critical Whiteness Studies', Borderlands, vol. 3, no. 2, 2004), and Damien Riggs (Damien Riggs, “'We don't talk about race anymore": Power, Privilege and Critical Whiteness Studies', Borderlands, vol. 3, no. 2, 2004). These two camps stand at opposite ends of a political spectrum and might mock each other with labels of 'white blindfolds' and 'black arm bands'. Notwithstanding my admittedly polemic next sentence, I do hope these writers and others affiliated with them read this article.

${ }^{20}$ K. Everett, 'Welcome to Country ... Not', Oceania, vol. 79, no. 1, 2009; K. Lambert-Pennington, 'What Remains? Reconciling Repatriation, Aboriginal Culture, Representation and the Past', Oceania, vol. 77, no. 3, 2007; and G. Cowlishaw, 'Mythologising Culture', The Australian Journal of Anthropology, vol. 22, 2011. For a discussion of the Maori version, see H. Levine, 'Visiting Tieke Kāainga: The Authenticity of a Maori Welcome', Oceania, vol. 81, 2011. Two additional papers on this topic are E. Dempster, 'Welcome to Country: Performing Rights and the Pedagogy of Place', About Performance, vol. 7, 2007; and G. McAuley, 'Unsettled Country: Coming to Terms with the Past', About Performance, vol. 9, 2009. 
${ }^{21}$ E. Kowal, 'The Politics of the Gap: Indigenous Australians, Liberal Multiculturalism and the End of the Self-determination Era', American Anthropologist, vol. 11, no. 3, 2008 and E. Kowal, Trapped in the Gap: Doing Good in Indigenous Australia, Berghahn, New York \& London, 2015.

22 E. Goffman, Stigma: Notes on the Management of Spoiled Identity, Prentice-Hall, Englewood Cliffs, N.J., 1963; E. Kowal, 'The Stigma of White Privilege: Australian Anti-racists and Indigenous Improvement', Cultural Studies, vol. 25, no. 3, 2011.

${ }^{23}$ Whiteness studies is an enormous field, but key foundations texts establishing Whiteness as a form of privilege include R. Frankenberg, White Women, Race Matters: The Social Construction of Whiteness, University of Minnesotta Press, Minneapolis, 1993; R. Dyer, White, Routledge, London and New York, 1997; and Michelle Fine, Lois Weis, Linda Powell and L. Mun Wong, Off White: Readings on Race, Power and Society, Routledge, New York, 1997. For a comprehensive treatment of the relationship between White privilege and White stigma see Kowal, 'The Stigma of White Privilege'.

24 A. Moreton-Robinson, Whitening Race: Essays in Social and Cultural Critisicm, Aboriginal Studies Press, Canberra, 2004. A. Moreton-Robinson, 'The House that Jack Built: Britishness and White Possession', Australian Critical Race and Whiteness Studies Association Journal, vol. 1, no. 2, 2005. A. Moreton-Robinson, 'The Possessive Logic of Patriarchal White Sovereignty: The High Court and the Yorta Yorta Decision', Borderlands, vol. 3, no. 2, 2004.

25 Certain other spaces share this property of attempting to invert colonial power relations and thus make White privilege, its long history and its negative effects more visible. Examples include a university Indigenous studies course, an Indigenous solidarity group, or an Indigenous protest rally. It should be noted that attempts to invert colonial power relations can, almost by definition, never succeed in a settler colony. There are always limits to Indigenous recognition by anti-racist people and the liberal state. This is clear at several points in the material I discuss below.

26 E. Kowal, 'Stigma and Suffering: White Anti-racist Identities in Northern Australia', Postcolonial Studies, vol. 15, no. 1, 2012.

27 S. Ahmed, 'Declarations of Whiteness: The Non-Performativity of Anti-Racism', Borderlands, vol. 3, no. 2, 2004.

${ }^{28}$ Ahmed readily admits her analysis may be experienced as 'useless' because she is 'not prescribing what an anti-racist whiteness studies would be, or by not offering some suggestions about "what white people can do"', and she is 'happy to take that risk' (Ahmed, 'Declarations of Whiteness', para 58). As I state above, my analysis involves a reciprocal risk-of letting the White anti-racist off the hook, one could say-that I am prepared to take.

29 T. Dreher, 'Eavesdropping with Permission: The Politics of Listening for Safer Speaking Places', Borderlands, vol. 8, no. 1, 2009; F. Probyn, 'Playing Chicken at the Intersection: The White Critic of Whiteness', Borderlands, vol. 3, no. 2, 2004. See also Riggs, “'We don't talk about race anymore”' and Haggis, 'Beyond Race and Whiteness?'.

30 Riggs. 
31 Respectively, Kowal, 'The Stigma of White Privilege' and Kowal, 'Stigma and Suffering'.

32 The painful experience of 'not belonging' can be understood as a form of suffering. (Kowal, 'Stigma and Suffering').

33 The terminology of 'progressives' and 'conservatives' refer to Australians that identify with views that are typically classified as left-wing or progressive (such as pro-choice and collective bargaining, land rights, reconciliation, supporting asylum seekers), and right-wing or conservative (such as reducing welfare and reducing tax, opposing affirmative action), respectively. In this article they are used as heuristic categories that are necessarily generalising. Individual Australians may see themselves as conservative on some issues and progressive on others, or may identify with both or neither of those labels. The label 'progressive' is aligned with an 'anti-racist' identity. This does not mean that conservatives cannot identify as 'anti-racist', but that the dominant discourse of Australian conservativism is generally not associated with anti-racism.

34 E. Goffman, The Presentation of Self in Everyday Life, Doubleday, Garden City, NY, 1959.

35 The term 'native ethnographer' is most commonly used to refer to a non-White anthropologist working in their home country (K. Narayan, 'How Native is a 'Native' Anthropologist?', American Anthropologist, vol. 95, no. 3, 1993), but I use because I, like my informants, am a White, middle-class, educated, progressive professional who worked in Indigenous affairs.

36 Parts of the empirical material in this section draw on E. Kowal, Trapped in the Gap: Doing Good in Indigenous Australia, Berghahn, New York and London, 2015.

37 For example A. Moreton-Robinson, Talkin' Up to the White Woman: Indigenous Women and Feminism, University of Queensland Press, Brisbane, 2000 and L. T. Smith, Decolonizing Methodologies, Research and Indigenous Peoples, 2nd edn, Zed Books Ltd, London \& New York, 2012.

38 Author's fieldnotes, 16 September 2004. Note that Kylie's main employment as a senior project officer was with another organisation. Her role here was to discuss a policy she had contributed to developing for the research organisation running the workshop. She was not paid for this.

${ }^{39}$ Author's fieldnotes 19 July 2004.

${ }^{40}$ Author's fieldnotes, 20 September 2004.

41 See also Tim Dauth, 'Group Names and Native Title in South-east Australia', in T. Bauman and G. Macdonald (eds), Unsettling Anthropology: The Demands of Native Title on Worn Concepts and Changing Lives, Australian Institute of Aboriginal and Torres Strait Islander Studies, Canberra, 2011.

42 John Conroy, 'Aborigines Interrupt “Welcome””, Border Mail, 16 October 2009.

${ }^{43}$ NSW Health, Welcome to Country Protocols Policy, Department of Health, Sydney, New South Wales, 2005.

${ }^{44}$ Such contestations are documented in the anthropological literature (see, for example C. Adams, 'Ethics, Power and Politics in Aboriginal Health Research', The Asia Pacific Journal of Anthropology, vol. 3, no. 2, 2002; P. Batty, 'Private Politics, Public Strategies: White Advisers and their Aboriginal Subjects', Oceania, vol. 75, no. 3, 2005; W. Sanders, Thinking About Indigenous Community Governance, 
Centre for Aboriginal Economic Policy Research, Canberra, 2004; and R. Tonkinson, 'Aboriginal "Difference" and "Autonomy" Then and Now: Four Decades of Change in a Western Desert Society', Anthropological Forum, vol. 17, no. 1, 2007).

45 K. Windschuttle, 'Sacred Traditions Invented Yesterday', Quadrant, vol. 56, 2012.

46 J. Masanauskas and C. Gillet, 'Kennett Hails Baillieu's Move Away from Indigenous

Acknowledgments', Herald Sun, 19 May 2011.

47 Masanauskas and Gillet.

48 D. Trigger, personal communication, 29 May 2009.

${ }^{49}$ ABC Online Indigenous-News, ‘Ex-Victorian premiers back Aboriginal welcome’, 2011.

50 L. Pearson, 'Unleashed', ABC Online, 4 May 2010.

51 The apology, performed the same day as the first WTC to occur in the Australian Parliament, concerned Aboriginal and Torres Strait Islander people who were removed from their families into state institutions for much of the twentieth century (Human Rights and Equal Opportunity Commission, Bringing Them Home: Report of the National Inquiry into the Separation of Aboriginal and Torres Strait Islander Children from Their Families, Human Rights and Equal Opportunity Commission, Canberra, 1997, <http://www.austlii.edu.au/au/special/rsjproject/rsjlibrary/hreoc/stolen/>). Parts of this paragraph and a few that follow are reworked from a 'Newsreel' piece that appeared in Meanjin (E. Kowal, 'Welcome to Country?', Meanjin, vol. 69, no. 2, 2010).

52 J. Atkinson, Trauma Trails, Recreating Song Lines: The Transgenerational Effects of Trauma in Indigenous Australia, Spinifex Press, Melbourne, 2002.

53 A.D. Moses, 'Official Apologies, Reconciliation, and Settler Colonialism: Australian Indigenous Alterity and Political Agency', Citizenship Studies, vol. 15, no. 2, 2011.

54 M. Johnson, 'Reconciliation, Indigeneity, and Postcolonial Nationhood in Settler States', Postcolonial Studies, vol. 14, no. 2, 2011.

55 Everett, p. 60.

56 Related to this is the critique of WTCs and Acknowledgements as appropriating 'Aboriginal primordial links to the land which cannot otherwise be claimed by the Australian state', Everett, p. 55; see also A. Lattas, 'Essentialism, Memory and Resistance: Aboriginality and the Politics of Authenticity', Oceania, vol. 63, no. 3, 1993.

57 M. Hinkson, 'Encounters with Aboriginal Sites in Metropolitan Sydney: A Broadening Horizon for Cultural Tourism?', Journal of Sustainable Tourism, vol. 11, no. 4, 2003.

58 Everett, p. 58.

59 Ibid.

60 Victor Hart, personal communication, 15 April 2009. See Veracini's arguments on settler colonial desires for Indigenous disappearance and the use of measures ostensibly aimed at equality, recognition, and reconciliation for assimilationist aims. Lorenzo Veracini, 'Introducing Settler Colonial Studies', Settler Colonial Studies, vol. 1, no. 1, 2011. 
61 Everett.

62 Povinelli, The Cunning of Recognition.

${ }^{63}$ Andrew Bolt, 'Don't Welcome Me to My Own Country', Herald Sun, 15 March 2010.

64 Pearson.

65 Masanauskas and Gillet.

66 Comments made on online article by Pearson (cited in Pearson).

67 S. Convery, 'Lip Service', Overland, 16 March 2010, <https://overland.org.au/2010/03/lip-service/>.

68 Kowal, 'Stigma and Suffering' and Kowal, 'The Stigma of White Privilege'.

${ }^{69}$ Ahmed.

${ }^{70}$ See for example Richard J. Martin and David Trigger, 'Negotiating Belonging: Plants, People, and Indigeneity in Northern Australia', Journal of the Royal Anthropological Institute, vol. 21, no. 2, 2015. I suspect Ahmed would object to this turn, labelling it as a form of 'alongsideness', part of number 6 of her 'non-performative declarations of whiteness' (see Ahmed). However, as mentioned earlier, this is a risk I am willing to take.

${ }^{71}$ Although I am reluctant to authorise my suggestion for an inclusive Acknowledgement by saying 'Indigenous people are doing it too' or 'did it first', as this rehearses the kind of anti-racist gesture I am analysing, some Indigenous people are in fact 'doing it too'. My own Acknowledgement was inspired by one I have heard given at different events by Professor Ngiare Brown that acknowledges the ancestors of all people present.

\section{-BIBLIOGRAPHY}

ABC Online Indigenous News, 'Ex-Victorian premiers back Aboriginal welcome', 6 December 2011.

ACT Government: Community Services, 'Welcome to Country', 2012,

<http://www.dhcs.act.gov.au/atsia/welcome_to_country>

Adams, C., 'Ethics, Power and Politics in Aboriginal Health Research', Asia Pacific Journal of Anthropology, vol. 3, no. 2, 2002. doi: http://dx.doi.org/10.1080/14442210210001706286

Ahmed, S., 'Declarations of Whiteness: The Non-Performativity of Anti-Racism', Borderlands, vol. 3, no. $2,2004$.

Atkinson, J., Trauma Trails, Recreating Song Lines: The Transgenerational Effects of Trauma in Indigenous Australia, Spinifex Press, Melbourne, 2002.

Austin, J.L., How to do Things with Words: The William James Lectures delivered at Harvard University in 1955, Oxford University Press, London, 1962.

Batty, P., 'Private Politics, Public Strategies: White Advisers and their Aboriginal Subjects', Oceania, vol. 75, no. 3, 2005. doi: http://dx.doi.org/10.1002/j.1834-4461.2005.tb02881.x

Bolt, A., 'Baillieu Made the Right Call on Welcome Ceremonies', Herald Sun, 6 December 2011, <http://www.heraldsun.com.au/opinion/baillieu-made-the-right-call-on-welcomeceremonies/story-e6frfifx-1226059908884>. 
Bolt, A., 'Don't Welcome Me to My Own Country', Herald Sun, 15 March 2010.

Conroy, John, 'Aborigines Interrupt “Welcome”, Border Mail, 16 October 2009.

Convery, S., 'Lip Service', Overland, 16 March 2010, <https://overland.org.au/2010/03/lip-service/>.

Correy, S., 'The Reconstitution of Aboriginal Sociality Through the Identification of Traditional Owners in New South Wales', Australian Journal of Anthropology, vol. 17, no. 3, 2006. doi: http://dx.doi.org/10.1111/j.1835-9310.2006.tb00068.x

Cowlishaw, G., 'Mythologising Culture', Australian Journal of Anthropology, vol. 22, 2011.

Dauth, T., 'Group Names and Native Title in South-east Australia', in T. Bauman and G. Macdonald (eds), Unsettling Anthropology: The Demands of Native Title on Worn Concepts and Changing Lives, Australian Institute of Aboriginal and Torres Strait Islander Studies, Canberra, 2011.

Dempster, E., 'Welcome to Country: Performing Rights and the Pedagogy of Place', About Performance, vol. 7, 2007.

Dreher, T., 'Eavesdropping with Permission: The Politics of Listening for Safer Speaking Places', Borderlands, vol. 8, no. 1, 2009.

Dyer, R., White, Routledge, London and New York, 1997.

Elder, C., Being Australian: Narratives of National Identity, Allen \& Unwin Sydney, 2007.

Everett, K., 'Welcome to Country... Not', Oceania, vol. 79, no. 1, 2009. doi: http://dx.doi.org/10.1002/j.1834-4461.2009.tb00050.x

Fine, M., L. Weis, L. Powell and L. Mun Wong, Off White: Readings on Race, Power and Society, Routledge, New York, 1997.

Fitznor, L., 'Indigenous Scholars and Writing through Narratives and Storying for Healing and Bridging', in L. Fitznor and J. Hendry (eds), Anthropologists, Indigenous Scholars and the Research Endeavour: Seeking Bridges towards Mutual Respect, vol. 5, Routledge, New York, 2012.

Frankenberg, R., White Women, Race Matters: The Social Construction of Whiteness, University of Minnesotta Press, Minneapolis, 1993.

Gelder, K., and J. Jacobs, Uncanny Australia: Sacredness and Identity in a Postcolonial Nation, Melbourne University Press, Melbourne, 1998.

Goffman, E., Stigma: Notes on the Management of Spoiled Identity, Prentice-Hall, Englewood Cliffs, NJ, 1963.

Goffman, E., The Presentation of Self in Everyday Life, Doubleday, Garden City, NY, 1959.

Hage, G., Against Paranoid Nationalism: Searching for Hope in a Shrinking Society, Pluto Press, Sydney, 2003.

Hage, G., White Nation: Fantasies of White Supremacy in a Multicultural Society, Pluto Press, Sydney, 1998.

Haggis, J., 'Beyond Race and Whiteness? Reflections on the New Abolitionists and an Australian Critical Whiteness Studies', Borderlands, vol. 3, no. 2, 2004. 
Hinkson, M., 'Encounters with Aboriginal Sites in Metropolitan Sydney: A Broadening Horizon for Cultural Tourism?', Journal of Sustainable Tourism, vol. 11, no. 4, 2003. doi: http://dx.doi.org/10.1080/09669580308667208

Human Rights and Equal Opportunity Commission, Bringing Them Home: Report of the National Inquiry into the Separation of Aboriginal and Torres Strait Islander Children from Their Families, Human Rights and Equal Opportunity Commission, Canberra, 1997, <http://www.austlii.edu.au/au/special/rsjproject/rsjlibrary/hreoc/stolen/>.

Johnson, M., 'Reconciliation, Indigeneity, and Postcolonial Nationhood in Settler States', Postcolonial Studies, vol. 14, no. 2, 2011.

Kowal, E., Trapped in the Gap: Doing Good in Indigenous Australia, Berghahn, New York \& London, 2015.

Kowal, E., 'Stigma and Suffering: White Anti-racist Identities in Northern Australia', Postcolonial Studies, vol. 15, no. 1, 2012.

Kowal, E., 'The Stigma of White Privilege: Australian Anti-racists and Indigenous Improvement', Cultural Studies, vol. 25, no. 3, 2011. doi: http://dx.doi.org/10.1080/09502386.2010.491159

Kowal, E., 'Welcome to Country?', Meanjin, vol. 69, no. 2, 2010.

Kowal, E., 'The Politics of the Gap: Indigenous Australians, Liberal Multiculturalism and the End of the Self-determination Era', American Anthropologist, vol. 11, no. 3, 2008. doi: http://dx.doi.org/10.1111/j.1548-1433.2008.00043.x

Lambert-Pennington, K., 'What Remains? Reconciling Repatriation, Aboriginal Culture, Representation and the Past', Oceania, vol. 77, no. 3, 2007. doi: http://dx.doi.org/10.1002/j.18344461.2007.tb00019.x

Lattas, A., 'Essentialism, Memory and Resistance: Aboriginality and the Politics of Authenticity', Oceania, vol. 63, no. 3, 1993. doi: http://dx.doi.org/10.1002/j.1834-4461.1993.tb02420.x

Levine, H., 'Visiting Tieke Kāainga: The Authenticity of a Maori Welcome', Oceania, vol. 81, 2011.

McAuley, G., 'Unsettled Country: Coming to Terms with the Past', About Performance, vol. 9, 2009.

McKenna, M., 'Tokenism or Belated Recognition? Welcome to Country and the Emergence of Indigenous Protocol in Australia, 1991-2014', Journal of Australian Studies, vol. 38, no. 4, 2014. doi: http://dx.doi.org/10.1080/14443058.2014.952765

Martin, R.J. and D. Trigger, 'Negotiating Belonging: Plants, People, and Indigeneity in Northern Australia', Journal of the Royal Anthropological Institute, vol. 21, no. 2, 2015. doi: http://dx.doi.org/10.1111/1467-9655.12206

Masanauskas, J. and C. Gillet, 'Kennett Hails Baillieu's Move Away from Indigenous Acknowledgments', Herald Sun, 19 May 2011.

Merlan, F., 'Recent Rituals of Indigenous Recognition in Australia: Welcome to Country', American Anthropologist, vol. 116, no. 2, 2014. doi: http://dx.doi.org/10.1111/aman.12089

Moran, A., Australia: Nation, Belonging and Globalization, Routledge, New York, 2005. 
Moran, A., 'Trust and Uncertainty in a Settler Society: Relations between Settlers and Aborigines in Australia', in S. Watson and A. Moran (eds), Trust, Risk and Uncertainty, Palgrave Macmillan, New York, 2005.

Moreton-Robinson, A., 'The House that Jack Built: Britishness and White Possession', Australian Critical Race and Whiteness Studies Association Journal, vol. 1, no. 2, 2005.

Moreton-Robinson, A., Whitening Race: Essays in Social and Cultural Critisicm, Aboriginal Studies Press, Canberra, 2004.

Moreton-Robinson, A., 'The Possessive Logic of Patriarchal White Sovereignty: The High Court and the Yorta Yorta Decision', Borderlands, vol. 3, no. 2, 2004.

Moreton-Robinson, A., 'I Still Call Australia Home: Indigenous Belonging and Place in a White Postcolonizing Society', in S. Ahmed, C. Castaneda, A. Fortier and M. Sheller (eds), Uprootings/Regroundings: Questions of Home and Migration, Berg, Oxford, 2003.

Moreton-Robinson, A., Talkin' Up to the White Woman: Indigenous Women and Feminism, University of Queensland Press, Brisbane, 2000.

Morris, B., 'Anthropology and the State: The Ties That Bind', Social Analysis: The International Journal of Social and Cultural Practice, vol. 47, no. 1, 2003.

Moses, A.D., 'Official Apologies, Reconciliation, and Settler Colonialism: Australian Indigenous Alterity and Political Agency', Citizenship Studies, vol. 15, no. 2, 2011. doi: http://dx.doi.org/10.1080/13621025.2011.549698

Narayan, K., 'How Native is a “Native” Anthropologist?', American Anthropologist, vol. 95, no. 3, 1993. doi: http://dx.doi.org/10.1525/aa.1993.95.3.02a00070

Nicoll, F., “'Are You Calling Me a Racist?”: Teaching Critical Whiteness Theory in Indigenous Sovereignty', Borderlands, vol. 3, no. 2, 2004.

NSW Health, Welcome to Country Protocols Policy, Department of Health, Sydney, New South Wales, 2005.

O’Brien, A. and L. Hall, 'Dingo Claims the First Welcome', Australian, 17 March 2010.

Paradies, Y., 'Beyond Black and White: Essentialism, Hybridity and Indigeneity', Journal of Sociology, vol. 42, no. 4, 2006. doi: http://dx.doi.org/10.1177/1440783306069993

Pearson, L., 'Unleashed', ABC Online, 4 May 2010.

Perera, S., 'Who will I Become? The Multiple Formations of Australian Whiteness', Australian Critical Race and Whiteness Studies Association Journal, vol. 1, 2005.

Povinelli, E., Economies of Abandonment: Social Belonging and Endurance in Late Liberalism, Duke University Press, Durham, 2011. doi: http://dx.doi.org/10.1215/9780822394570

Povinelli, E., The Cunning of Recognition: Indigenous Alterities and the Making of Australian Multiculturalism, Duke University Press, Durham and London, 2002. doi: http://dx.doi.org/10.1215/9780822383673 
Probyn, F., 'An Ethics of Following and the No Road Film: Trackers, Followers and Fanatics', Australian Humanities Review, vol. 37, 2005.

Probyn, F., 'Playing Chicken at the Intersection: The White Critic of Whiteness', Borderlands, vol. 3, no. 2,2004 .

Reconciliation Australia, 'Reconciliation Australia: Reconciliation Action Plans', <http://www.reconciliation.org.au/raphub/about/>.

Riggs, D., “'We don't talk about race anymore”: Power, Privilege and Critical Whiteness Studies', Borderlands, vol. 3, no. 2, 2004.

Riphagen, M., 'Black on White: Or Varying Shades of Grey? Indigenous Australian Photo-media Artists and the "Making of' Aboriginality"', Australian Aboriginal Studies, no. 1, 2008.

Russell, L., “Either, or, Neither Nor":Resisting the Production of Gender, Race and Class Dichotomies in the Pre-Colonial Period', in E. Conlin Casella and C. Fowler (eds), The Archaeology of Plural and Changing Identities, Springer, New York, 2005. doi: http://dx.doi.org/10.1007/0-306-48695$\underline{4} 3$

Sanders, W., Thinking About Indigenous Community Governance, Centre for Aboriginal Economic Policy Research, Canberra, 2004.

Smith, L.T., Decolonizing Methodologies, Research and Indigenous Peoples, second edn, Zed Books Ltd, London and New York, 2012.

Tonkinson, R., 'Aboriginal "Difference" and "Autonomy" Then and Now: Four Decades of Change in a Western Desert Society', Anthropological Forum, vol. 17, no. 1, 2007. doi: http://dx.doi.org/10.1080/00664670601168476

Veracini, L., 'Introducing Settler Colonial Studies', Settler Colonial Studies, vol. 1, no. 1, 2011. doi: http://dx.doi.org/10.1080/2201473X.2011.10648799

Windschuttle, K., 'Sacred Traditions Invented Yesterday', Quadrant, vol. 56, 2012.

Windschuttle, K., The Fabrication of Aboriginal History, Macleay Press, Sydney, 2002.

Young, I.M., Justice and the Politics of Difference, Princeton University Press, Princeton, 1990. 